\title{
The Use of Serenoa Repens (Saw Palmetto) in Hair Care Products
}

\author{
Joanna Igielska Kalwat* \\ Faculty of Cosmetology and Educational Sciences, Poland
}

Received: 誹: December 21, 2018; Published: 制: January 11, 2019

*Corresponding author: Joanna Igielska Kalwat, Faculty of Cosmetology and Educational Sciences, Poland

\begin{abstract}
The following paper describes saw palmetto, a plant that found its use already in the 19th century. Nowadays, it is still used in medicine, pharmacy and cosmetology. Serenoa extract is a potent 5-AR inhibitor, the use of which reduces the destructive DHT level. Saw palmetto also affects the inhibition of testosterone and DHT binding to cytoplasmic and nuclear androgen receptors. The already mentioned $5 \alpha$-dihydrotestosterone (DHT) is one of the causes of androgenic alopecia. Alopecia in both women and men is one of the most significant aesthetic problems of modern times.
\end{abstract}

Keywords: Serenoa Repens; Saw Palmetto; Trichology; Hair Loss Problem

\section{Introduction}

Saw palmetto it is a plant that growns in the United States, Central, North and South America and West Indies. In the USA, it can be found in the marshy areas of Florida, North Carolina, Alabama and Texas. Palm fruit is characterized by purple-black coloring. It grows in clusters, and the fruiting period falls in October - December. Ripe and partially dried fruits are used to prepare extracts. In traditional medicine, the interest in saw palmetto goes back to the beginning of the $19^{\text {th }}$ century. Native Americans consumed this plant to overcome the problems associated with prostatic hyperplasia, or testicular swelling and atrophy. In 1926, saw palmetto was officially introduced into the pharmaceutical market, but around 1950 it was withdrawn due to the lack of confirmed medicinal properties. Studies on the plant were relaunched in the 1980s.

\section{Description of the Research Problem}

Serenoa repens (W. Bartram) Small plant belongs to the Arecaceae family. It is a monoicous palm tree with thin bark. This species is long-lived and can grow for 500-700 years. It has an underground rhizome from which 3 to 7 leaves grow every year. The leaves are leathery, green or white-green in color, characterized by both palmoid and fan shape. The petioles are spiny, longer than the leaf blade, and covered with sharp spines, which is why the saw palmetto is often called the lateral serrate palm. The flowers are small, white and gathered in panicles growing from the leaf angles. The palm is pollinated by insects and blooms from April to July. During ripening, the fleshy fruit exhibits dark red and then blue-black color. They have an ellipsoidal shape [1]. The healing raw material consists of the dried, mature fruit - Sabalis serrulatae fructus of Serenoa repens. The fruit must contain at least $11 \%$ of fatty acids. The raw material is sourced exclusively from the wild. The fruit can be eaten raw, or in the form of an extract enclosed in a capsule, tincture or tablet [2].

The main components of the fruit and extract obtained from them is the lipid-sterol fraction. This fraction includes triglycerides, phytosterols (beta-sitosterol, stigminerol, campesterol, cycloartenol), fatty acids (capric, caproic and caprylic, lauric, myristic, oleic and palmitic), their ethyl esters and triglycerides. Saw palmetto also contains kaempferol, quercetin, isoquercitrin, roifolin, farnesol, lupeol, lupenone, uronic acids, arabinose, galactose, polysaccharides, resins and tannins. Biological active monoacylglycerides (1-monolaurine and 1-monomyristin) with cytotoxic activity on human prostate cells were isolated from the raw material [3]. Due to its beneficial composition, saw palmetto has found application in the food, pharmaceutical, medical and cosmetics industries. The Maya used Serenoe repens as a tonic. In Florida, Native Americans have been using palms since the 1700s to treat inflammation, as an expectorant and antiseptic. Extract from saw palmetto contributes to the reduction in the activity level of enzyme responsible for transforming testosterone into $5 \alpha$-hydrotestosterone (DHT) a hormone whose elevated level causes numerous ailments of the urinary tract. This can be manifested by among others infertility, 
hormonal failure of male or female reproductive organs, testicular tumors and polycystic ovary syndrome [4].

Elevated levels of DHT are responsible for prostate growth which is manifested by abdominal pain and problems with passing urine [1]. The consequence of prostatic hypertrophy may be complete urinary retention in the body. Phytosterols contained in the saw palmetto limit the cholesterol absorption process. Cholesterol is involved in the formation of DHT hormone [5]. Extracts of saw palmetto fruit treat voiding disorders in patients with prostatic hypertrophy, reduce urinary retention in the bladder and improve urine flow. They contribute to the reduction of swelling of prostatic mucous membranes and muscles, as well as cause the disappearance of burning and pain during urination or urgent need to pass urine; finally, they inhibit the growth of prostate cancer. Saw palmetto fruit exhibit anti-swelling and anti-inflammatory effects (phytosterols), inhibit the formation of inflammatory mediators, and have immunostimulatory effect (polysaccharides). Flavonoids are responsible for anti-inflammatory and anti-exudative effects, and they also improve blood circulation. Saw palmetto extract also act as antiaggregatives and stimulate epithelial and muscle regeneration [6-7].

Extract of saw palmetto fruit contributes to inhibiting the formation of inflammatory mediators. This action occurs by inhibiting the arachidonic acid cascade (reduction of 5-lipoxygenase activity). Blocking of androgen activity by saw palmetto extract, as well as its anti-edema activity was confirmed in animal studies. In in vivo experiments, it was found that the administration of extract together with hormones (testosterone and estradiol) results in inhibited prostate weight gain in castrated rats [8]. Palm fruit (Serenoa repens) extract is a preparation that has an effective and safe effect on human health. It is well tolerated by the majority of patients. The best therapeutic effects can be achieved when using extract of dried fruit that has been obtained by extracting the raw material (using $\mathrm{CO}_{2}$, in supercritical conditions, with preservation of specific temperature and pressure parameters). This extract can be directly used in treatment without further purification [9]. Appropriate doses of Serenoa repens extract range from 800 to $1200 \mathrm{mg}$ per day. Therapy should last at least 4-6 months. Preparations of saw palmetto fruit bring effective effects also in rheumatism, gout, generalized inflammation and in autoimmune disorders (psoriasis, urticaria, pemphigus and atopic dermatitis), because they inhibit the release of mediators of inflammation and pain.

The sabal palm is also used as a sedative and to increase sex drive (aphrodisiac). It is utilized in the treatment of chronic migraine headaches. Serenoe repens can be used in patients with asthma, throat diseases, colds, bronchitis, flu-like illnesses, influenza and pertussis. It is very useful with excessive secretion of mucus from the sinuses and the nose $[10,11]$. In the cosmetics industry, saw palmetto fruit have found application in preparations intended for scalp and hair care. The plant in question is antiandrogenic, and therefore can be used in the treatment of androgenetic alopecia [12]. Excessive hair loss is caused by many environmental factors such as inadequate diet, irritating cosmetics and stress. In approximately
95\% of cases, baldness are caused by hormones - androgens. Androgenetic alopecia is an increased or rapid hair loss without simultaneous physical changes on the skin. The type of baldness discussed here is one of the most severe problems affecting mainly men. The progressive process of baldness contributes to the lack of acceptance towards one's appearance. Therefore, manufacturers of scalp and hair care cosmetics make every effort to isolate the active substance that will effectively combat the problem.

The most dangerous for the hair is dihydrotestosterone (DHT), which is a stronger and more active testosterone derivative. Testosterone is transformed into dihydrotestosterone (DHT), in a reaction catalysed by 5-alpha-reductase catalysed enzyme (5-AR) [13]. Serenoa extract is a potent 5-AR inhibitor, the use of which reduces the destructive DHT level. Saw palmetto also affects the inhibition of testosterone and DHT binding to cytoplasmic and nuclear androgen receptors. The already mentioned $5 \alpha$-dihydrotestosterone (DHT) is one of the causes of androgenic alopecia. Sebaceous glands contain also 5-alpha-reductase - an enzyme that converts testosterone into DHT. Research confirms that it is the high level of DHT (and not testosterone, as it is generally believed) that causes hair loss. This hormone contributes to the miniaturization of hair follicles, which leads to a shortening of the hair's lifespan and its incorrect production. The hair becomes thinner, lighter and shorter. This type of baldness mainly affects men and is manifested by the loss of hair on the top of the head and at the base of the forehead. However, it may also affect women with endocrine disorders or with a fall in female hormones after pregnancy or during menopause $[14,15]$. Treatment of androgenetic alopecia involves the inhibition of 5-alpha-reductase activity. This is the best way to reduce the impact of DHT on the hair follicles. Synthetic drugs are used (finasteride and dutasteride), but in lower doses than in the treatment of prostatic hypertrophy. An alternative to synthetic drugs in the prevention of androgenetic alopecia are preparations containing saw palmetto extract.

In the market of dietary supplements, several preparations containing this raw material may be found. They are recommended to people struggling with not so much with androgenic alopecia, as with worsened condition of hair and skin. Typically, such products contain also vitamins A, E, C and silicone. Saw palmetto extract can also be found in hair care products: shampoos (e.g. Ducray Sabal), masks and conditioners (e.g. O'Herbal) [16-18]. Pharmacies offer a vast array of preparations containing sabal palmetto extract, but the vast majority belong to the category of dietary supplements. These preparations do not have medicinal properties. In Poland, only two drugs are available containing a standardized extract from saw palmetto: Prostamol Uno and Sterko. Their advantage over other preparations with this raw material results from the rigorous procedure of introducing and controlling medicinal products that are subject to the Chief Pharmaceutical Inspector. Dietary supplements are controlled by the Sanitary and Epidemiological Station (Państwowa Inspekcja Sanitarna) in a selective manner only, and their true qualitative and quantitative composition does not always coincide with the manufacturers' declarations. 
Both drugs alleviate ailments associated with the initial stage of benign prostatic hyperplasia. In addition to the aforementioned medicines based on saw palmetto extract, supplements with this ingredient may also be found on the market (Table 1) [19]. Saw palmetto is a potential therapeutic in androgenetic alopecia affecting both women and men. In addition to the oral application, there is a much less invasive form, not affecting the hormonal balance of the whole organism - a direct application to the scalp in the form of a shampoo, conditioner or scalp extract. In the fight against androgenetic alopecia, the most effective are shampoos, masks and rub-in compounds with extract of saw palmetto fruit. They can also be used in prevention of hair loss [22]. Extract from saw palmetto has also found application in the treatment of androgenic acne, hirsutism (virilism in women) and hyperandrogenism. Saw palmetto is a component of anti-acne preparations as well as shampoos and hair masks regulating the secretion of sebum [23]. In rare cases, the researchers observed side effects such as mild dizziness and headache, nausea, vomiting, constipation or diarrhea. Using palmetto extract may reduce blood coagulation as well as increase the tendency to bruises and bleedings. Therefore, people who have a planned surgical procedure should stop using saw palmetto at least two weeks before. The preparation is not recommended during pregnancy and breastfeeding or when using contraceptives. This plant may cause irreversible damage to the fetus or lead to a miscarriage [24,25].

Table 1: Examples of preparations containing saw palmetto extract, available in Polish pharmacies [19-21].

\begin{tabular}{|c|c|c|c|}
\hline The Name of the Preparation & Application & Category & Manufacturer \\
\hline Prostamol Uno & Treatment of mild prostate hypertrophy & Medicinal product & Berlin Chemie \\
\hline Sterko & Treatment of mild prostate hypertrophy & Medicinal product & Glenmark \\
\hline Saw Palmetto & $\begin{array}{l}\text { Supporting the treatment of mild prostatic } \\
\text { hypertrophy }\end{array}$ & Dietary supplement & Solgar \\
\hline MultiProsti & $\begin{array}{l}\text { Supporting the treatment of mild prostatic } \\
\text { hypertrophy }\end{array}$ & Dietary supplement & +Pharma Arzneimittel \\
\hline Gold-Vit for men & Vitamin supplement for men & Dietary supplement & Olimp Laboratories \\
\hline Rutiver & Vitamin supplement for men & Dietary supplement & Biovena \\
\hline Profolan & Stimulation of hair growth, DHT block & Dietary supplement & Profolan \\
\hline Prostatan & Proper prostate function, hair growth stimulation & Dietary supplement & Olimp Labs \\
\hline Prostenal Perfect & $\begin{array}{l}\text { Support of prostate function and health of the } \\
\text { genitourinary and urinary tract }\end{array}$ & Dietary supplement & Walmarkt \\
\hline O’Herbal shampoo & Weak hair needing reinforcement & Cosmetic & Elfa Pharm \\
\hline O’Herbal conditioner & $\begin{array}{c}\text { Weak } \\
\text { hair needing reinforcement }\end{array}$ & Cosmetic & Elfa Pharm \\
\hline O’Herbal mask & Weak hair needing reinforcement & Cosmetic & Elfa Pharm \\
\hline Ducray Sabal & Shampoo for oily hair & Cosmetic & Ducra \\
\hline
\end{tabular}

\section{Conclusion}

The development of technology, cosmetology, medicine and consumer awareness forces the manufacturers to search for new active substances of both plant and synthetic origin. They are supposed to positively influence the problems related to both our health and beautiful appearance. One controversial plant that has been used in the fight against androgenic alopecia is saw palmetto, described in the above paper.

\section{References}

1. Strzelecka H, KowalskiJ (2000) Encyklopedia zielarstwai ziołolecznictwa. In Strzelecka H, Kowalski J (Eds.) PWN, Warszawa, Poland.

2. Wink M (2008) Rośliny lecznicze świata. Med. Pharm Polska. Wrocław, Poland.

3. Węglarscy J (2008) Użyteczne rośliny tropików. Wyd. Naukowe Bogucki. Poznań,.

4. Bennet BC, Hicklin JR (1998) Uses of Saw-Palmetto (Serenoa repens, Arecaceae) in Florida. Econ Botan 52(4): 381-393.
5. Bast A, Chandler RF, Choy PC, Delmulle LM, Gruenwald J, et al. (2002) Botanical health products, positioning and requirements for effective and safe use. Environ. Toxicol. Pharmacol 12(4): 195-211.

6. Blumenthal M, Gruenwald J, Hall T (1998) German Commission E monographs: therapeutic monographs on medicinal plants. American Botanical Council. Austin, TX.

7. Bombardelli E, Morazzoni P (1997) Serenoa repens. Fitoterapia 68(2): 99-113.

8. Breu W, Hagenlocher M, Redl K, Tittel G, Stadler F, et al. (1992) Anti-inflammatory activity of Sabal fruit extracts prepared with supercritical carbon dioxide. In vitro antagonists of cyclooxygenase and 5-lipooxygenase metabolism. Arzneim Forsch 42(4): 547-555.

9. Cristoni A, Morazzoni P, Bombardelli E (1997) Chemical and pharmacological study on hypercritical $\mathrm{CO} 2$ extracts of Serenoa repens fruits. Fitoterapia 68: 355-358.

10. Karłowicz Bodalska (2004) Znaczenie ekstraktu z owoców palmy Serenoa repens (Sabal serrulata) w leczeniu łagodnego rozrostu gruczołu krokowego. Postępy Fitoterapii 2: 95-98.

11. Marderosian A (2000) Saw palmetto in the review of natural products. Facts and Comparisons, St. Louis. 
12. Di Silverio F, D’Eramo G, Lubrano C, Flammia GP, Sciarra A, et al. (1992) Evidence that Serenoa repens extract displays an antiestrogenic activity in prostatic tissue of benign prostatic hypertrophy patients. Eur Urology 21(4): 309-314.

13. Di Silverio F, Flammia GP, Sciarra A, Caponera M, Mauro M, et al. (1993) Plant extracts in BPH. Minerva Urol. Nefrol 45(4): 143-149.

14. Dobrev H (2007) Clinical and instrumental study of the efficacy of a new sebum control cream. J of Cosm Derma 6(2): 113-118.

15. Duke JA, Bogenschutz Godwin MJ, Cellier J, Duke PAK (2002) Handbook of medicinal herbs. In Duke JA, Bogenschutz Godwin MJ, Cellier J, Duke PAK (Eds.) CRC Press, London.

16. Ejchman W (2004) BPH-fitoterapia. Zalety i działania niepożądane. Przegląd Urologiczny 5: 23.

17. ESCOP Monographs (2003) The Scientific Foudation for Herbal Medicinal Produkts: Fructus Serenoe repentis, Thieme, pp. 477-486.

18. Farmakopea Polska VIII (I, II, III) (2008) Urząd Rejestracji Produktów Leczniczych, Warszawa, Poland.

19. Kurth H (1998) Saw Palmetto extracts - standardization, characterization and analytical comparison of finished products. Presentation at the 1998

\section{ISSN: 2574-1241}

DOI: 10.26717/BJSTR.2019.13.002348

Joanna Igielska Kalwat. Biomed J Sci \& Tech Res

(C) (i) This work is licensed under Creative

Submission Link: https://biomedres.us/submit-manuscript.php
International Saw Palmetto Symposium. American Herbal Products Association, Naples (USA).

20. Lamer Zarawska E, Kowal Gierczak B, Niedworok J (2007) Fitoterapia i leki roślinne. PZWL, Warszawa, Poland.

21. Levin RM, Das AK (2000) A scientific basis for the therapeutic effects of Pygeum africanum and Serenoa repens. Urology Res 28(3): 201-210.

22. Prager N, Bickett K, French N, Marcovici G (2002) A randomized, double-blind, placebo-controlled trial to determine the effectiveness of botanically derived inhibitors of 5-alpha-reductase in the treatment of androgenetic alopecia. J Altern Complement Med 8(2): 143-152.

23. Schaffner W (1996) Rośliny lecznicze - chemizm działanie, zastosowanie. In Schaffner W (Eds.) Wyd. Multico, Warszawa, Poland.

24. Shimada H Tyler VE, McLaughlin JL (1997) Biologically active acylglycerides from the berries of Saw-Palmetto (Serenoa repens). J Nat Prod 60(4): 417-418.

25. Marks LS, Hess DL, Dorey FJ, Luz Macairan M, Cruz Santos PB, et al. (2001) Tissue effect of Saw palmetto and finasteride: use of biopsy cores for in situ quantufication of prostatic androgens. Urology 57(5): 9991005.

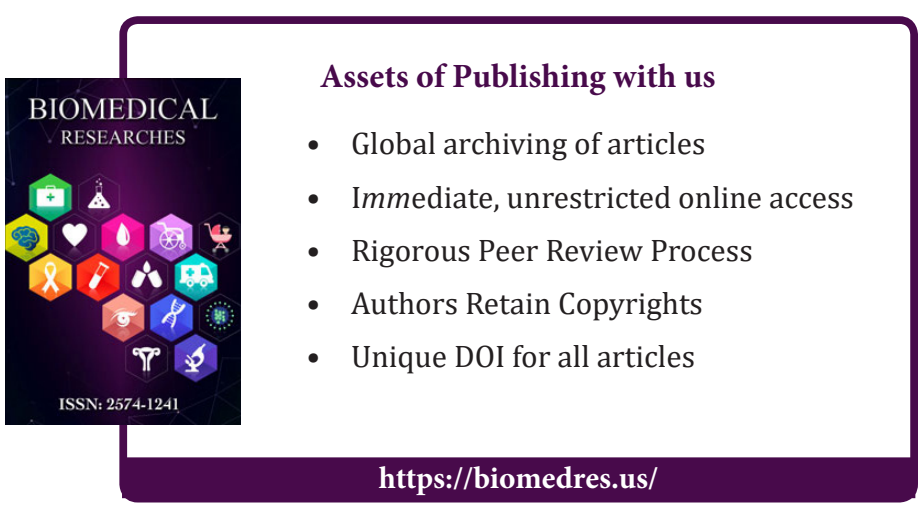

